\title{
ANALISA KUALITAS PELAYANAN DAN STRATEGI PERUSAHAAN TERHADAP KEPUASAN PELANGGAN DENGAN METODE QFD DAN SWOT PADA JASA PENGIRIMAN BARANG
}

\author{
Bonaventura Andhika W \\ Program Studi Magister Manajemen Universitas Tarumanagara \\ navendhika@gmail.com
}

Masuk : 06-12-2020, revisi : 14-12-2020, diterima untuk diterbitkan : 15-12-2020

\begin{abstract}
Goods delivery services become the most profitable business opportunities. Facing the reality of the number of goods or services with diverse quality and consumer tastes are easy to change and there are several competitors in this field, resulting in a sharper level of competition. With the growing number of freight services competitors, each delivery service provider such as JNE, TIKI, and Pos Indonesia need to have a special strategy to improve customer satisfaction. This study aims to examine the service quality from each delivery service provider to customer satisfaction through IPA and QFD methods and SWOT analysis to establish the company's strategy in maintaining its position in the market is facing competitors. CSI results obtained for goods delivery services in Jakarta are in the category of quite satisfied but have not reached the maximum satisfaction point. Using the IPA method, researchers found that Pos Indonesia delivery service is one of the delivery services that need to be improved the service quality to be able to survive. Attributes that affect the services and targets that are the priority of Pos Indonesia are based on the QFD method, namely the need for training to employees to be able to improve their service quality. In addition, the right strategic steps to be taken by Pos Indonesia are intensive strategies including market penetration, market development, and service product development to accelerate the company's growth. This strategy is strongly related to the proposed design of strength and opportunity strategies that have been analyzed through SWOT analysis methods.
\end{abstract}

Keywords: Service Quality, CSI, IPA, QFD, SWOT

\begin{abstract}
Abstrak: Jasa pelayanan pengiriman barang menjadi salah satu peluang bisnis yang sangat menguntungkan. Menghadapi kenyataan banyaknya barang atau jasa dengan kualitas beragam dan selera konsumen yang mudah berganti serta terdapat beberapa pesaingdibidang ini, mengakibatkan tingkat persaingan semakin tajam. Semakin bertambahnya pesaing-pesaing dari jasa pelayanan pengiriman barang, masing-masing penyedia jasa pengiriman barang seperti JNE, TIKI dan Pos Indonesia perlu memiliki strategi khusus untuk meningkatkan kepuasan pelanggan. Penelitian ini bertujuan untuk mengkaji kualitas pelayanan dari masingmasing penyedia jasa pengiriman barang terhadap kepuasan pelanggannya melalui pendekatan metode IPA dan QFD serta untuk menetapkan strategi perusahaan dalam mempertahankan posisinya dipasar dalam menghadapi pesaing melalui analisa SWOT. Pada penelitian ini, didapatkan hasil CSI untuk jasa pengiriman barang di Jakarta berada dalam kategori cukup puas namun belum mencapai titik kepuasan maksimum. Dalam analisa menggunakan metode IPA, peneliti menemukan bahwa jasa pengiriman Pos Indonesia, merupakan salah satu jasa pengiriman yang perlu ditingkatkan kualitas pelayanannya untuk dapat bertahan. Atribut yang mempengaruhi pelayanan dan target yang menjadi prioritas Pos Indonesia didasarkan pada metode QFD, yaitu perlunya pelatihan kepada karyawan untuk dapat meningkatkan kualitas pelayanannya. Selain itu, langkah strategis yang tepat untuk dilakukan oleh Pos Indonesia yaitu strategi intensif meliputi penetrasi pasar, pengembangan pasar dan pengembangan produk layanan untuk mempercepat pertumbuhan perusahaan. Strategi ini berkaitan sangat kuat
\end{abstract}


dengan rancangan usulan strategi kekuatan dan peluang yang telah dianalisa melalui metode analisa SWOT.

Kata Kunci: Kualitas Pelayanan, CSI, IPA, QFD, SWOT

\section{PENDAHULUAN}

\section{Latar Belakang}

Jasa pelayanan pengiriman barang menjadi salah satu peluang bisnis yang sangat menguntungkan. Menghadapi kenyataan banyaknya barang atau jasa dengan kualitas beragam dan selera konsumen yang mudah berganti serta terdapat beberapa pesaing dibidang ini, mengakibatkan tingkat persaingan semakin tajam.Tingginya permintaan pengiriman barang di Indonesia, tidak terlepas dari campur tangan beberapa penyedia jasa pengiriman barang yang tumbuh di Indonesia. Masing-masing penyedia jasa pengiriman barang mempunyai strategi khusus untuk meningkatkan kepuasan pelanggan. Perusahaan Penyedia jasa pengiriman barang seperti TIKI, JNE, dan Pos Indonesia terus bersaing untuk mendapatkan pelanggan dengan strategi pemasaran yang berbeda-beda. Semakin bertambahnya pesaing-pesaing dari jasa pelayanan pengiriman barang, perusahaan TIKI, JNE dan Pos Indonesia harus mengetahui kelemahan-kelemahan dan mengembangkannya agar terus mendapat kepercayaan dari konsumen. Analisis mutu pelayanan menggunakan Quality Fuctional Deployment adalah cara yang tepat untuk mengetahui faktor penting yang memiliki pengaruh terhadap kepuasan pelanggan, selain itu untuk lebih memahami karekteristik perusahaan maka menggunakan SWOT menjadi salah satu cara untuk melengkapi dasar strategi yang harus diterapkan dan dikembangkan, dengan mempertimbangkan faktor internal maupun faktor eksternal dari perusahaan jasa pengiriman terutama untuk PT Pos Indonesia.

\section{Tujuan Penelitian}

Penelitian ini dilakukan dengan tujuan:

1. Mengetahui karakteristik responden penggunaan jasa pengiriman barang terhadap jenis jasa pelayanan pengiriman barang di Jakarta dengan cara penyebaran kuesioner penelitian.

2. Mengetahui tingkat kepuasan konsumen terhadap jasa pelayanan pengiriman barang di Jakarta berdasarkan penggunaan metode Customer Satisfaction Index dengan cara mengelompokan atribut ke dalam 7 dimensi variabel dan mencari hubungan antara masing-masing atribut dengan tingkat kepentingan dan tingkat kinerja perusahaan.

3. Mengetahui atribut yang menjadi prioritas utama yang harus ditingkatkan berdasarkan penggunaan metode Importance Performance Analysis dengan cara mengukur hubungan antara persepsi konsumen dan prioritas peningkatan kualitas jasa.

4. Mengetahui prioritas usulan untuk lebih meningkatkan kepuasan pelanggan berdasarkan penggunaan metode Quality Functional Deployment dan menghasilkan matrix HOQ untuk menunjukkan target prioritas dalam perbaikan kualitas pelayanan perusahaan.

5. Mengetahui penentuan perencanaan strategi perusahaan jasa pengiriman barang di Jakarta berdasarkan penggunaan metode analisa SWOT. Analisa dilakukan untuk merumuskan strategi perusahaan baik dari sisi internal ataupun eksternal perusahaan.

\section{TINJAUAN PUSTAKA}

\section{Improvement Performance Analysis (IPA)}

Metode Improvement Performance Analysis (IPA) bertujuan untuk untuk mengukur hubungan antara persepsi konsumen dan prioritas peningkatan kualitas produk/jasa yang dikenal pula sebagai quadrant analysis (Brandt, 2000). IPA mempunyai fungsi utama untuk menampilkan informasi berkaitan dengan faktor-faktor pelayanan yang menurut konsumen sangat mempengaruhi kepuasan dan loyalitas mereka, dan faktor-faktor pelayanan yang menurut konsumen perlu ditingkatkan karena kondisi saat ini belum memuaskan. IPA secara konsep merupakan suatu model multi-atribut. Tehnik ini mengidentifikasi kekuatan dan 
kelemahan penawaran pasar dengan menggunakan dua kriteria yaitu kepentingan relatif atribut dan kepuasan konsumen (Latu \& Everett, 2000).

\section{Quality Function Deployment (QFD)}

Qualtity Function Deployment adalah metodologi untuk menterjemahkan keinginan dan kebutuhan konsumen ke dalam suatu rancangan produk yang memiliki persyaratan teknis dan karakteristik kualitas tertentu (Akao, 1990; Urban \& Hauser, 1993). Penggunaan metodologi QFD dalam proses perancangan dan pengembangan produk merupakan suatu nilai tambah bagi perusahaan barang atau jasa. Sebab perusahaan akan mempunyai keunggulan kompetitif dengan meciptakan suatu produk atau jasa yang mampu memuaskan konsumen (Gaspersz, 2001). Langkah-langkah pada tahap ini secara ringkas dapat dijelaskan sebagai berikut: 1) Mengklarifikasi kebutuhan pelanggan; 2) Mengumpulkan data-data kualitatif; 3) Analisa data pelanggan; 4) Kuantifikasi Data.

\section{House of Quality (HOQ)}

Tahap pertama QFD umumnya dikenal sebagai house of quality (HOQ), merupakan kepentingan mendasar dan strategis dalam sistem QFD, pada fase ini kebutuhan pelanggan akan produk yang telah diidentifikasi dan selanjutnya, memprioritaskan penggabungan untuk produksi perusahaan, diubah menjadi langkah-langkah yang tepat untuk memenuhi kebutuhan. Dengan kata lain HOQ menggabungkan antara "voice of the customer" dengan "voice of the technician", dengan ini proses dan rencana produksi dapat dibentuk pada tahap sistem QFD lainnya.

\section{Analisis Lingkungan Eksternal}

Analisis lingkungan eksternal adalah sesuatu kekuatan yang berada di luar perusahaan dimana perusahaan tidak mempunyai pengaruh sama sekali terhadapnya (uncontrolable) sehingga perubahan-perubahan yang terjadi pada lingkungan ini akan mempengaruhi kinerja semua perusahaan dalam industri tersebut. Menjabarkan kekuatan-kekuatan analisa eksternal utama dapat dibagi menjadi lima kategori luas (David, 2012): 1) kekuatan ekonomi; 2) kekuatan sosial, budaya, demografis, dan lingkungan; 3) kekuatan politik, pemerintahan, dan hukum; 4) kekuatan teknologi; dan 5) kekuatan kompetitif. Untuk menganalisa faktor-faktor lingkungan luar/eksternal bisnis dapat dilakukan dengan menggunakan teknik analisa PESTEL, dan analisa lingkungan industri (Five Forces Porter).

\section{Analisis Lingkungan Internal}

Analisa internal menurut Porter (1998, p. 33) yang dikenal dengan rantai nilai yang memposisikan perusahaan pada matriks strategi generik dan menemukan keunggulan bersaing perusahaan melalui analisa kompetensi inti. Rantai nilai ini mensyaratkan bahwa untuk mencapai suatu margin, perusahaan harus didukung oleh kegiatan utama dan penunjang. Kegiatan utama merupakan aktivitas utama perusahaan, meliputi fungsi: 1) Logistik Kedalam; 2) Operasi; 3) Logistik Keluar; 4) Pemasaran dan Penjualan; 5) Pelayanan.Fungsi penunjang merupakan aktivitas pendukung perusahaan yang meliputi pengadaan, pengembangan teknologi, manajemen sumber daya manusia, dan infrastruktir perusahaan. Analisa lingkungan internal dapat dilakukan dengan menggunakan berbagai macam cara diantaranya dengan menggunakan pendekatan berbasis sumber daya (Resource Based View/RBV) untuk merespon dan membangun keunggulan bersaing di pasar.

\section{Matrix SWOT}

Analisis SWOT adalah evaluasi terhadap keseluruhan kekuatan, kelemahan, peluang dan ancaman. Menurut David (2009), matrik SWOT adalah sebuah alat untuk mengidentifikasi kecocokan suatu kepentingan yang membantu manajer mengembangkan empat tipe strategi: SO (kekuatan-peluang), WO (kelemahan-peluang), ST (kekuatan-ancaman), dan WT (kelemahan-ancaman). Mencocokan faktor eksternal dan internal kunci adalah bagian tersulit dalam mengembangkan matrik SWOT. Menurut Jogiyanto (2005), SWOT sangat diperlukan dalam menilai kekuatan-kekuatan maupun kelemahan-kelemahan dari sumber-sumber daya yang dimiliki oleh perusahaan serta menilai kesempatan-kesempatan eksternal maupun 
tantangan-tantangan yang dihadapi. Dalam menentukan rancangan bisnis model, akan digunakan analisis matriks.

\section{METODE PENELITIAN}

Penelitian ini dilakukan proses pengumpulan data dengan menggunakan questionnaires yang disebar secara langsung kepada para responden dan pengamatan langsung proses bisnis pada perusahaan di cabang yang akan dilakukan penelitian. Pada penelitian ini, sample yang digunakan dalam penelitian ini berjumlah 150 responden. Hasil kuesioner di uji validitas dan uji reliabilitas untuk menguji apakah data kuesioner dapat diandalkan, konsisten dan dijadikan sebuah alat ukur untuk memperoleh informasi yang digunakan dalam penelitian ini. Pengolahan uji data dilakukan dengan menggunakan SPSS. untuk mengetahui seberapa besar tingkat kepuasan konsumen atas kualitas jasa pelayanan dilakukan dengan menggunakan metode CSI, Nilai rata-rata persepsi dan harapan konsumen yang telah didapatkan berdasarkan hasil perhitungan kuesioner kemudian dipetakan kedalam Importance Performance Matrix dan didapatkan 4 kuadran yang mengelompokkan atribut-atribut kuesioner berdasarkan tingkat kepentingan dan kinerja. Selanjutnya, penentuan target/goal yang perlu dilakukan oleh penyedia jasa pengiriman barang untuk dapat meningkatkan kualitas pelayanan demi mencapai kepuasan konsumen ditentukan berdasarkan ranking/prioritas yang didapat dari matriks HOQ.Selain meningkatkan dan mempertahankan kualitas pelayanan, perusahaan juga diharapkan dapat mempertahankan posisinya dalam pasar.Adanya penilaian SWOT membantu untuk menetapkan prioritas mana saja yang harus didahulukan oleh perusahaan, mengetahui potensi pasar, minat dan peluang pasar yang bisa dimanfaatkan. Selain itu, perusahaan akan dapat mengetahui tingginya tingkat persaingan pasar.

\section{HASIL DAN PEMBAHASAN}

Dari hasil uji validitas dan uji reliabilitas pada data hasil penyebaran kuesioner kepada 150 responden, menunjukkan hasil uji validitas tingkat kepentingan dan tingkat kinerja jasa pelayanan pengiriman barang, untuk setiap kelompok dimensi dinyatakan valid pada masingmasing atributnya dengan hasil $\mathrm{R}$ hitung lebih besar dari nilai $\mathrm{R}$ tabel pada signifikansi $5 \%$. Dan untuk hasil uji reliabilitas tingkat kepentingan dan tingkat kinerja jasa pelayanan pengiriman barang setiap kelompok dimensi dinyatakan reliabel dengan hasil $\mathrm{R}$ alpha lebih besar dari 0,6 .

Hasil pengukuran CSI kepuasan konsumen atas kualitas jasa pelayanan pengiriman barang di Jakarta sebesar $61,56 \%$ tergolong cukup puas namun belum mencapai titik kepuasan maksimal. Dalam hal ini, perusahaan memerlukan upaya untuk meningkatkan kepuasan konsumen dan menjaga loyalitas pelanggan dengan memperbaiki factor-faktor kepuasan pelanggan tersebut. Berdasarkan hasil pengukuran CSI untuk jasa pengiriman barang secara keseluruhan di wilayah Jakarta, didapatkan hasil CSI untuk jasa pengiriman barang JNE sebesar, 67,28\% tergolong puas, TIKI sebesar 59,63\% tergolong cukup puas, dan Pos Indonesia sebesar 36,04\% tergolong kurang puas.

Dari hasil analisa IPA dengan pemetaan importance performance matrix, Pos Indonesia memiliki nilai kinerja yang paling rendah dengan jumlah atribut terbanyak yang perlu dipertahankan, diperbaiki dan ditingkatkan kinerjanya.

Hasil diskusi dengan pihak perusahaan, ada 19 poin technical responses yang perlu dilakukan Pos Indonesia beserta target/goal untuk memenuhi kebutuhan dan kepuasan konsumen. Hubungan antara atribut dengan technical responses tersebut tertuang dalam matriks HOQ dan menghasilkan urutan/ranking dari target yang menjadi prioritas utama perbaikan kualitas pelayanan dari perusahaan. Didapatkan hasil untuk prioritas pertama target yang perlu diprioritaskan oleh perusahaan adalah pelatihan ketrampilan dan kepemimpinan untuk menciptakan karyawan yang terampil dan professional sehingga dapat menjawab kebutuhan konsumen berdasarkan atribut kecepatan pelayanan customer services, kecepatan 
menanggapi penanganan keluhan, kesopanan karyawan dalam memberikan pelayanan pelanggan, menanggapi keluhan konsumen dengan baik, dan ada layanan customer care yang baik. Dilanjutkan dengan urutan prioritas berikutnya, yaitu perusahaan perlu menyediakan staff khusus bagian informasi keterlambatan, mendukung peningkatan motivasi dan kinerja karyawan, memperbaiki system logistik secara terus menerus, mengurangi keluhan pelanggan, menghindari kehilangan barang saat pengiriman, pelatihan program teknologi informasi, memastikan informasi perusahaan tersampaikan kepada konsumen, peningkatan kepercayaan pelanggan, bertanggung jawab dengan memberikan pengembalian biaya kepada konsumen, melakukan maintenance prasarana cabang setiap 6 bulan sekali, peningkatan kinerja customer service, pembukaan cabang baru, memberikan asuransi untuk setiap barang, mengoptimalkan aktivitas karyawan, mempercepat pengiriman barang, memberikan estimasi waktu pengiriman barang, harga pengiriman yang jelas untuk konsumen, dan melakukan pengarsipan dokumen yang baik.

Berdasarkan hasil pengolahan data dan penentuan prioritas target persusahaan maka selanjutnya untuk dapat bertahan dipasar dan dapat terus bersaing analisa SWOT dapat membantu perusahaan mengetahui aspek-aspek penting dari kekuatan, kelemahan, peluang, dan ancaman yang ada didalam perusahaan Pos Indonesia. Analisa faktor internal dan analisa faktor eksternal dilakukan agarmampu mengetahui posisi perusahaan dan perumusan strategi yang bisa diterapkan, berdasarkan hasil perhitungan didapatkan skor pada faktor internal sebesar 2.85 danpada faktor external sebesar 3.45, dari hasil ini peneliti bisa memposisikan matriks IE berada di posisi kuadran II, dimana posisi strategis PT Pos Indonesia masuk dalamposisi Grow and Build yang dapat diartikan bahwa kondisi perusahaan sedang bertumbuh dan berkembang.

Berdasarkan studi strategi yang cocok dan umumnya digunakan, langkah strategis yang dapat dilakukan oleh PT Pos Indonesia yaitu strategi intensif meliputi penetrasi pasar, pengembangan pasar, dan pengembangan produk.

Hasil analisa posisi kuadran SWOT, posisi perusahaan PT Pos Indonesia berada di kuadran 1 yang posisi ini menandakan bahwa PT Pos Indonesia sedang ada dalam posisi yang kuat dan sudah on the track. Yang perlu dilakukan adalah melakukan ekspansi, memperbesar serta mempercepat pertumbuhan perusahaan, sehingga hasil ini berkaitan sangat kuat dengan rancangan usulan strategi kekuatan dan peluang (S-O). Didapatkan hasil untukanalisa SWOT yaitu 3 butir usulan rancangan strategi kekuatan terkait dengan peluang yaitu membuka cabang baru di daerah yang berpotensi positif, memperluas dan menambahjaringan kerjasama dengan mitra bisnis seperti halnya e-commerce, membuat tarif yang terjangkau dengan tujuan mempertahankan dan meningkatkan loyalitas pelanggan.

\section{KESIMPULAN DAN SARAN}

Berdasarkan hasil analisis data dan kesimpulan yang telah didapatkan, ditemukan bahwa tingkat kinerja perusahaan mempengaruhi tingkat kepuasan konsumen. Dalam hal ini peneliti melakukan beberapa metode untuk menganalisa kualitas layanan, dengan memberikan usulan serta prioritas target yang perlu dicapai oleh perusahaan dan strategi yang diperlukan dalam mempertahankan posisi perusahaan. Berdasarkan hasil ini, maka penulis memberikan beberapa saran kepada perusahaan.

Pertama, hasil penelitian ini menunjukan bahwa responden pengguna jasa pengiriman barang pada khususnnya PT Pos Indonesia saat ini sangatlah sedikit. Saran peneliti kepada PT Pos Indonesia untuk meningkatkan pengguna jasa pelayanan pengiriman barang dengan cara menjalin kerjasama dengan beberapa e-commerce guna meningkatkan pengguna dan menambahkan brand awareness PT Pos Indonesia itu sendiri.

Kedua, hasil penelitian menunjukan bahwa responden pengguna jasa pengiriman barang pada khususnya PT Pos Indonesia saat ini mulai pindah menggunakan fasilitas layanan jasa pengiriman barang lainnya. Saran peneliti terhadap hal terkait adanya peningkatan media 
promosi yang harus diperbaiki oleh PT Pos Indonesia dengan memanfaatkan media teknologi dan cakupan pengiriman yang luas guna memberikan harga yang lebih kompetitif dengan pesaing atau perusahaan jasa pengiriman barang lainnya.

Terakhir, hasil penelitian menunjukan bahwa responden pengguna jasa pengiriman barang pada khususnya PT Pos Indonesia saat ini mementingkan pelayanan yang baik dan pemberian asuransi terhadap barang yang dikirim, saran peneliti untuk meningkatkan kepuasan pelanggan PT Pos Indonesia dengan salah satunya melakukan training SDM baik secara internal ataupun external untuk meningkatkan pelayanan yang diberikan serta memberikan informasi terkait lokasi barang (tracking) terhadap barang yang sedang dikirim dengan memberikan informasi bisa melalui SMS, Email ataupun lainnya.

\section{DAFTAR PUSTAKA}

Akao, Y. (1990). Quality function deployment (QFD) - Integrating customers's requirements into product design (English tr). Productivity Press.

Brandt, D. R. (2000). An "Outside-In" approach to determining customer driven priorities for improvement and innovation (Vol. 2-2). White Paper Series.

David, F. R. (2009). Manajemen strategis konsep (Buku 1). Salemba Empat.

David, F. R. (2012). Strategic management concepts and cases. Prentice Hall.

Gaspersz, V. (2001). Total Quality Management. PT Gramedia Pustaka Utama.

Jogiyanto, H. M. (2005). Analisa dan desain sistem informasi: Pendekatan terstruktur teori dan praktik aplikasi bisnis. Andi.

Latu, T. M., \& Everett, A. M. (2000). Review of satisfaction research and measurement approaches. Department of Conservation.

http://mama.zozlak.org/ZlozoneModeleSkalowaniaLiiniowego/LatuEverett_2000_Revie w of Satisfaction Research and Measurement Approaches.pdf

Porter, M. E. (1998). Competitive strategy: Techniques for analyzing industries and competitor. The Free Press.

Urban, G. L., \& Hauser, J. R. (1993). Design and marketing of new products (2nd ed.). Prentice Hall. 